\title{
EFEKTIVITAS ORGANISASI PASCA PERUBAHAN ORGANISASI BADAN KEPEGAWAIAN PENDIDIKAN DAN PELATIHAN DAERAH KOTA BITUNG PROVINSI SULAWESI UTARA
}

\author{
Oleh \\ Helty Marcelina Lengkong ${ }^{1}$, \\ Ermaya Suradinata ${ }^{2}$, M. Irwan Tahir ${ }^{3}$ \\ 1) Institut Pemerintahan Dalam Negeri \\ Program Magister Terapan Studi Pemerintahan Daerah Institut Pemerintahan Dalam Negeri \\ ninalengkong@gmail.com \\ 2,3) Institut Pemerintahan Dalam Negeri
}

\begin{abstract}
$G_{s}$ ood governance is one of the government's efforts to realize an efficient and effective governance that can be achieve through bureaucratic reform. Bureaucracy in Indonesia has been assessed as still being influenced by the interests of certain groups or people. With the existence of bureaucratic reforms, it is expected to resolve these problems. Bureaucratic reform can be realized through the arrangement of the Regional Devices Organization regulated in the Government Regulation of the Republic of Indonesia Number 41 of 2007 which then changes to the Government Regulation of the Republic of Indonesia Number 18 of 2016 concerning Regional Devices. This regulation aims to create a government bureaucracy that is poor in structure but rich in functions, namely by providing maximum service to the community in order to create prosperity for the community. Changes to this regulation resulted in a change and a reduction in the structure of the Bitung City BKPPD with the typology of $C$.

The results of the study show that the effectiveness of the Bitung City BKKPD can still be said to be ineffective, this can be seen from job productivity, job satisfaction felt by employees and lack of resources. In addition, there are also factors that influence organizational effectiveness as stated by Richard M. Steers, among others, span of control, size of organization, size of work unit, interest in work, and communication within the organization. So that a strategy to improve organizational effectiveness is needed as analyzed in ASOCA, among others: (1) Improving human resource capacity through education and training which is the result of collaboration with outside parties, (2) Improving the quality of personnel management systems through new innovations, (3) Maximizing the implementation of duties and functions and supervision in the form of reward and punishment, (4) Maximizing the ability and intelligence of innovating HR to create the strategies needed to improve BKPPD organizational effectiveness along with technological developments supported by the availability of facilities and infrastructure and (5) Evaluating positions in the organizational structure in order to increase the number of human resources that can effectively support the organization.
\end{abstract}

Keywords: effectiveness, organization 


\begin{abstract}
AbstraK
Good Governance merupakan salah satu upaya pemerintah untuk mewujudkan suatu tata kelola kepemerintahan yang efisien dan efektif yang dapat diwujudkan melalui reformasi birokrasi. Birokrasi di Indonesia selama ini dinilai masih banyak dipengaruhi oleh kepentingankepentingan kelompok atau orang-orang tertentu. Dengan adanya reformasi birokrasi diharapkan dapat mengatasi permasalahan-permasalahan tersebut. Reformasi birokrasi dapat diwujudkan melalui penataan Organisasi Perangkat Daerah yang diatur dalam Peraturan Pemerintah Republik Indonesia Nomor 41 Tahun 2007 yang kemudian mengalami perubahan menjadi Peraturan Pemerintah Republik Indonesia Nomor 18 Tahun 2016 tentang Perangkat Daerah. Peraturan ini bertujuan untuk menciptakan suatu birokrasi pemerintahan yang miskin struktur tetapi kaya akan fungsi yakni dengan memberikan pelayanan yang maksimal kepada masyarakat dalam rangka menciptakan kesejahteraan pada masyarakat. Perubahan peraturan ini mengakibatkan adanya perubahan dan pengurangan struktur pada BKPPD Kota Bitung dengan tipologi $C$.

Hasil Penelitian menunjukkan bahwa efektivitas organisasi BKKPD Kota Bitung dapat dikatakan belum efektif hal ini dapat dilihat dari produktivitas kerja, kepuasan kerja yang dirasakan pegawai serta sumber daya yang masih kurang. Selain itu juga adanya faktor-faktor yang memengaruhi efektivitas organisasi sebagaimana dikemukakan Richard M. Steers antara lain rentang kendali, ukuran organisasi, ukuran unit kerja, ketertarikan pada pekerjaan, serta komunikasi dalam organisasi. Sehingga dibutuhkan strategi untuk meningkatkan efektivitas organisasi sebagaimana yang telah dianalisis dalam ASOCA antara lain: (1) Meningkatkan kemampuan SDM melalui pendidikan dan pelatihan yang merupakan hasil kerja sama dengan pihak luar, (2) Peningkatan manajemen sistem kepegawaian yang berkualitas melalui inovasiinovasi baru, (3) Memaksimalkan penyelenggaraan tugas dan fungsi dan pengawasan dalam bentuk reward dan punishment, (4) Memaksimalkan kemampuan dan kecerdasan berinovasi SDM untuk melahirkan strategi yang dibutuhkan dalam meningkatkan efektivitas organisasi BKPPD seiring dengan perkembangan teknologi yang didukung oleh tersedianya sarana dan prasarana, serta (5) Melakukan evaluasi jabatan pada struktur organisasi dalam rangka peningkatan jumlah SDM yang dapat menunjang penyelenggaraan organisasi secara efektif.
\end{abstract}

Kata kunci: efektivitas, organisasi

\section{PENDAHULUAN}

Dembukaan Undang-Undang Dasar Tahun 1945 Pasal 18 menjelaskan bahwa Indonesia adalah sebuah negara yang wilayahnya terbagi atas daerah-daerah provinsi dan daerah-daerah provinsi terbagi atas daerah-daerah kabupaten/ kota. Yang mana setiap daerahdaerah provinsi, kabupaten/kota memiliki pemerintahan daerah sendiri sebagaimana diatur dalam peraturan perundang-undangan. Pemerintahan Daerah merupakan penyelenggaraan urusan pemerintahan oleh Pemerintah Daerah dan DPRD menurut asas otonomi dan tugas pembantuan dengan prinsip otonomi seluas-luasnya. Penyelenggaraan pemerintahan daerah ini telah diatur dalam UndangUndang Nomor 23 Tahun 2014 tentang Pemerintahan Daerah sebagai perubahan dari Undang-Undang Nomor 32 Tahun 2004 tentang Pemerintahan Daerah. Penyelenggaraan Pemerintahan Daerah dilaksanakan oleh Kepala Daerah dan DPRD yang berkedudukan sebagai mitra yang sama atau sejajar akan tetapi mempunyai fungsi yang berbeda. Dalam melaksanakan tugasnya Kepala Daerah dan DPDR dibantu oleh Perangkat Daerah. Penyelenggaraan pemerintahan daerah yang didasarkan pada otonomi daerah harus didukung oleh adanya suatu birokrasi pemerintahan untuk 
mengelola kewenangan yang telah dilimpahkan. Birokrasi pemerintahan ini dituntut untuk mampu melaksanakan kegiatan pemerintahan, kemasyarakatan serta pembangunan secara efisien dan efektif. Birokrasi pemerintahan merupakan ujung tombak pelayanan publik pemerintahan.

Birokrasi di Indonesia lebih banyak dipengaruhi oleh kepentingan politik individu atau kelompok-kelompok tertentu sehingga pelayanan yang diberikan pada masyarakat tidak maksimal. Selain itu masalah birokrasi yang terjadi selama ini antara lain birokrasi yang besar dan gemuk sehingga menghabiskan banyak sumber daya daerah, tidak adanya kejelasan misi serta struktur tugas dan fungsi yang mengakibatkan adanya tumpang tindih tugas dan fungsi pada birokrasi pemerintahan. Dengan alasan-alasan itulah pemerintah melakukan suatu pembenahan pada birokrasi pemerintahan. Reformasi birokrasi dapat diwujudkan melalui penataan kelembagaan, penataan ketatalaksanaan, penataan sumber daya manusia/aparatur, akuntabilitas, serta pelayanan umum.

Penataan kelembagaan dapat dilakukan melalui memperbaiki visi dan misi organisasi sampai pada penataan organisasi dan struktur jabatan. Penataan kelembagaan atau organisasi perangkat daerah diarahkan pada terciptanya birokrasi yang efisien, efektif, ramping dan fleksibel sesuai dengan kebutuhan dan kemampuan daerah masing-masing sehingga dapat memberikan pelayanan yang maksimal pada masyarakat. Akan tetapi pada kenyataannya pembentukan dan penataan kelembagaan atau organisasi perangkat daerah ditafsirkan secara berbeda oleh masing-masing daerah dan cenderung dibentuk berdasarkan keinginan masing-masing daerah. Hal inilah yang menyebabkan terciptanya organisasi yang terlalu besar (oversizing) dan tidak didasarkan pada kebutuhan nyata di daerah yang bersangkutan. Hal ini sejalan dengan apa yang dituliskan dalam Sedarmayanti (2010:324), "adanya fakta kecenderungan organisasi perangkat daerah yang terlalu besar dan kurang didasarkan pada kebutuhan nyata di daerah dapat berimplikasi pada pembengkakan organisasi perangkat daerah secara signifikan". Dalam pengambilan keputusan pembentukan dan penataan organisasi perangkat daerah sering kali tidak didasarkan pada pertimbangan rasional objektif, efektif dan efisien tetapi mengarah pada nuansa politis sehingga menimbulkan pembengkakan organisasi perangkat daerah secara signifikan yang berpengaruh pada inefisien alokasi anggaran yang tersedia di masing-masing daerah.

Berlakunya Peraturan Pemerintah RI Nomor 18 Tahun 2016 tentang Perangkat Daerah ini bertujuan untuk memberikan arah dan pedoman yang jelas kepada Daerah dalam menata Perangkat Daerah yang berdasarkan prinsip efisien, efektif, dan rasional sesuai dengan kebutuhan nyata dan kemampuan masing-masing daerah serta adanya koordinasi, integrasi, sinkronisasi dan efektivitas serta komunikasi antara Pemerintah Pusat dan Pemerintah Daerah. Sebagai tindak lanjut terhadap Peraturan Pemerintah Republik Indonesia Nomor 18 Tahun 2016 ini Pemerintah Kota Bitung menetapkan Peraturan Daerah Nomor 8 Tahun 2016 tentang Pembentukan dan Susunan Perangkat Daerah Kota Bitung. Pada peraturan tersebut terdapat perbedaan signifikan, pada peraturan yang baru, terdapat 4 Badan Daerah yang terdiri dari 3 Tipe A dan 1 Tipe $C$ yakni Badan Kepegawaian Pendidikan dan Pelatihan Daerah Kota Bitung, seperti yang tertuang dalam Peraturan Wali Kota Bitung Nomor 54 tahun 2016 tentang Kedudukan, Susunan Organisasi, Tugas dan Fungsi serta Tata Kerja Badan Kepegawaian Pendidikan dan Pelatihan Daerah Kota Bitung yakni pada susunan struktur organisasi BKPPD yang mengakibatkan dihapusnya beberapa jabatan eselon II,III, 
dan IV yang menyebabkan beban kerja yang diemban semakin banyak akibat adanya penggabungan urusan baik pada sub bagian maupun pada masing-masing bidang sampai pada seksi-seksi. Selain itu dapat dilihat dari struktur organisasi yang ada, masih terdapat beberapa jabatan eselon IV yang kosong belum terisi dan beberapa staf pada masing-masing unit kerja. Hal ini tentunya akan berpengaruh pada penyelenggaraan organisasi akibat terbatasnya SDM yang dimiliki dalam hal ini tugas dan fungsi pada jabatan yang kosong ini dilimpahkan dan dikerjakan oleh pegawai yang lain, sehingga beban kerja yang dirasakan semakin bertambah. Selain itu jika dilihat dari ketersediaan ASN sebagai sumber daya pendukung keberlangsungan organisasi masih dibutuhkan penambahan dikarenakan penempatan jabatan fungsional belum merata pada masingmasing bagian, bidang atau seksi, Akibatnya beban kerja terkadang bertumpuk yang menyebabkan beberapa pekerjaan harus terbengkalai, sistem koordinasi yang terbangun masih dirasakan kurang karena banyaknya pekerjaan.

\section{Rumusan Masalah}

1. Bagaimanakah efektivitas organisasi pada Badan Kepegawaian Pendidikan dan Pelatihan Daerah Kota Bitung pasca berlakunya Peraturan Pemerintah Nomor 18 Tahun 2016 tentang Perangkat Daerah?

2. Faktor-faktor apa sajakah yang memengaruhi efektivitas organisasi Badan Kepegawaian Pendidikan dan Pelatihan Daerah Kota Bitung pasca berlakunya Peraturan Pemerintah Nomor 18 Tahun 2016 tentang Perangkat Daerah?

3. Bagaimana strategi BKPPD dalam meningkatkan efektivitas organisasi Badan Kepegawaian, Pendidikan dan Pelatihan Daerah Kota Bitung?

\section{KAJIAN PUSTAKA}

\section{Efektivitas Organisasi}

Secara umum efektivitas berasal dari kata dasar efektif, yang menurut KBBI memiliki arti efek, pengaruh, akibat atau dapat membawa hasil. Efektivitas memiliki pengertian keefektifan yang memiliki arti keadaan berpengaruh, kemanjuran, keberhasilan, hal berlakunya. Singkatnya efektivitas merupakan hubungan antara output dan tujuan. Selain itu efektivitas juga sering diartikan sebagai suatu keberhasilan dalam mencapai tujuan yang sudah ditetapkan sebelumnya. menurut Richard M. Steers (1985:46) efektivitas merupakan "sejauh mana organisasi melaksanakan seluruh tugas pokok keseluruhan atau mencapai semua sasarannya". Steers mengemukakan ada lima kriteria dalam pengukuran efektivitas organisasi antara lain sebagai berikut.

\section{Kemampuan menyesuaikan diri}

Kemampuan menyesuaikan diri atau fleksibilitas adalah kemampuan organisasi untuk meyesuaikan dengan perubahan yang terjadi serta bagaimana mengambil tindakan atas perubahan tersebut. Kunci keberhasilan suatu organisasi adalah adanya kerja sama antara individu dalam organisasi untuk pencapaian tujuan organisasi itu sendiri. Oleh karena itu, setiap individu tersebut dituntut untuk mampu menyesuaikan diri dengan lingkungannya baik dengan sesama individu dalam organisasi maupun pekerjaan dalam organisasi.

\section{Produktivitas}

Menurut Gibson (1997:22) produktivitas merupakan "kemampuan organisasi untuk memproduksi jumlah dan mutu output yang sesuai dengan permintaan lingkungan". Selain itu produktivitas dapat dikatakan sebagai adanya perbandingan antara hasil yang dicapai (output) dengan keseluruhan sumber 
daya yang digunakan (input) untuk mencapai tujuan organisasi atau dengan kata lain kemampuan organisasi untuk memperoleh hasil (output) dari sumber daya yang digunakan sesuai dengan permintaan lingkungan. Produktivitas organisasi dapat diukur melalui 3 tingkatan yakni tingkat individu, tingkat kelompok dan keseluruhan organisasi.

3. Kepuasan kerja

Kepuasan kerja yang dimaksud adalah tingkat kesenangan yang dirasakan seseorang atas peranan atau pekerjaan organisasi. Selain itu dapat dilihat juga pada tingkat kepuasan individu ketika mereka mendapatkan imbalan yang setimpal dari berbagai aspek situasi pekerjaan dan organisasi tempat mereka berada.

4. Kemampuan berlaba

Penghasilan atas penanaman modal yang dipakai untuk menjalankan organisasi. Jumlah sumber daya yang tersisa setelah biaya dan kewajiban dipenuhi.

5. Pencarian sumber daya

Kemampuan suatu organisasi untuk mengintegrasikan dan mengoordinasikan berbagai subsistem memiliki sumber daya yang diperlukan.

\section{Faktor-Faktor yang Memengaruhi Efektivitas Organisasi}

Richard M. Steers (1985) Efektivitas dalam suatu organisasi dipengaruhi oleh beberapa faktor antara lain sebagai berikut.

1. Karakteristik Organisasi

Karakteristik organisasi terdiri dari struktur dan teknologi organisasi. Struktur merupakan penyusunan atau pengelompokan orang-orang dalam suatu organisasi untuk melaksanakan dan menyelesaikan tugas yang sudah dibagikan. Adapun faktor-faktor yang meliputi struktur antara lain sebagai berikut.
a. Desentralisasi
b. Spesialisasi
c. Formalisasi
d. Rentang Kendali
e. Besar (ukuran) Organisasi
f. Besar (ukuran) Unit Kerja

2. Karakteristik Lingkungan

Lingkungan pekerjaan suatu organisasi mencakup dua aspek yakni lingkungan eksternal dan lingkungan internal. Steers mengemukakan lingkungan eksternal adalah "semua kekuatan yang timbul di luar batas-batas organisasi dan memengaruhi keputusan serta tindakan dalam organisasi".

3. Karakteristik Pekerja

Dalam organisasi pekerja merupakan salah satu faktor pendukung keberhasilan organisasi. Tanpa pekerja organisasi tidak dapat berfungsi. Pekerja dapat memengaruhi keefektifan suatu organisasi. Terciptanya tujuan organisasi tergantung pada kemampuan pekerja yang dimiliki organisasi tersebut. Perbedaan pandangan, tujuan, kebutuhan serta kemampuan masing-masing individu atau pekerja dalam suatu organisasi menjadi masalah utama sehingga dibutuhkan keterikatan terhadap yang kemudian nanti juga akan menentukan prestasi kerja yang dimiliki oleh para pekerja tersebut. Keterikatan organisasi terdiri dari ketertarikan, kemantapan kerja, keikatan (commitment). Sementara itu prestasi kerja dapat dilihat dari motivasi, tujuan dan kebutuhan, kemampuan serta kejelasan peran.

4. Kebijakan dan Praktik Manajemennya

Irwan Tahir dan Ani Martini dalam bukunya (2015) mengemukakan kebijakan dan praktik manajemen merupakan " mekanisme yang meliputi penetapan tujuan strategi, pencarian dan 
pemanfaatan sumber daya secara efisien, menciptakan lingkungan prestasi, proses komunikasi, kepemimpinan dan pengambilan keputusan, inovasi dan adaptasi organisasi". Henry Mintzberg yang dikutip Gibson at.al (1996:33) dalam Irwan Tahir dan Ani Martini mengemukakan ada tiga peran utama manajerial yakni pertama peran interpersonal yang melibatkan manajer dengan pihak lain di dalam maupun di luar organisasi, kedua peran pengambil keputusan melibatkan manajer dengan melihat dari sudut pandang operasional, alokasi sumber daya, dan negosiasi dengan unsur-unsur organisasi. dan ketiga peran informasi di mana manajer sebagai penerima atau pemberi informasi kepada berbagai individu atau institusi.

\section{ASOCA}

Ermaya Suradinata (2013:18) mengemukakan "analisis ASOCA, yaitu kepanjangan dari ability (kemampuan), strength (kekuatan), opportunities (peluang), culture (budaya) dan agility (kecerdasan)". Lebih lanjut dikatakan "culture (budaya) dan agility (kecerdasan) juga merupakan unsur penting dalam menentukan strategi pemecahan masalah, pengambilan keputusan serta dapat dikembangkan dalam mengikuti perubahan, perkembangan zaman dan kebutuhan ". Terminologi ASOCA menurut Suradinata (2013) antara lain sebagai berikut.

- Ability (kemampuan) merupakan kesanggupan, kecakapan yang dimiliki oleh suatu objek.

- Strength (kekuatan) merupakan ketangguhan, handal, kukuh serta keuletan.

- Opportunities (peluang) merupakan suatu kesempatan atau ruang gerak yang dimanfaatkan dalam rangka pencapaian tujuan.
- Culture (budaya) merupakan adat istiadat yang sudah berkembang dan menjadi kebiasaan yang sulit untuk diubah karena adanya kesempatan untuk terus memelihara.

- Agility (kecerdasan) merupakan pemikiran yang tajam, akal yang berkembang dan kepandaian serta kemampuan dalam mengelola pola pikir, menganalisis suatu informasi yang kemudian akan dijadikan keputusan.

Suradinata (2013) lebih lanjut menjelaskan analisis lingkungan internal terdiri dari sumber daya manusia, sarana dan prasaran, dukungan anggaran, dukungan informasi, dan capacity building.

Adapun analisis lingkungan eksternal terdiri dari faktor ekonomi, faktor masyarakat atau sosial, dan faktor teknologi.

\section{HASIL PENELITIAN}

\section{Kemampuan Menyesuaikan Diri}

Berdasarkan hasil wawancara dengan Kepala Bidang Diklat, Mutasi dan Pengembangan Aparatur Richard Wowiling dikatakan bahwa:

"Perubahan struktur organisasi ini sangat dirasakan lebih khusus pada tataran kepala bidang, karena sebelumnya dari empat bidang sekarang menjadi dua bidang salah satunya bidang diklat dan bidang mutasi digabung menjadi satu bidang. Oleh karena itu baik kepala bidang maupun staf harus menyesuaikan kembali dengan perubahan yang terjadi khususnya secara teknis pekerjaan karena bertambahnya tugas dan tanggung jawab kami. Karena organisasi harus berjalan terus mau tidak mau ya kami harus segera mungkin menyesuaikan diri dengan perubahan yang ada, sambil kami terus mempelajari tugas dan fungsi yang baru sesuai perubahan tersebut. 
Dibutuhkan waktu kurang lebih 1-3 bulan untuk kami menyesuaikan diri dengan perubahan itu. Sampai sekarang Puji Tuhan hampir semua pegawai bisa menyesuaikan diri sekali pun beban kerja yang dirasakan cukup besar".

Tabel 1 Perbedaan Struktur Organisasi Badan Kepegawaian Pendidikan dan Pelatihan Daerah Kota Bitung Sebelum dan Sesudah Perubahan

\begin{tabular}{lcc}
\hline \multirow{1}{*}{$\begin{array}{c}\text { Susunan } \\
\text { Organisasi }\end{array}$} & $\begin{array}{c}c \\
\text { PP No. 41 } \\
\text { Tahun 2007 }\end{array}$ & $\begin{array}{c}\text { PP No. 18 } \\
\text { Tahun 2016 }\end{array}$ \\
\cline { 2 - 3 } Kepala Badan & 1 & 1 \\
Sekretariat & 1 & 1 \\
Bidang & 4 & 2 \\
Sub Bagian & 3 & 2 \\
Sub Bidang & 8 & - \\
\hline Seksi & - & 6 \\
\hline
\end{tabular}

Sumber: Peraturan Wali Kota Bitung

Berdasarkan hasil studi dokumentasi dan wawancara di atas serta observasi penulis di lapangan dapat disimpulkan bahwa Badan Kepegawaian Pendidikan dan Pelatihan Daerah Kota Bitung dalam hal ini para pegawai baik Kepala Badan, Sekretaris, Kepala Sub Bagian, kepala Bidang, Kepala Seksi sampai para staf atau fungsional umum dinilai mampu menyesuaikan diri dengan perubahan struktur organisasi yang baru yakni Tipe C sesuai dengan Peraturan Pemerintah Nomor 18 Tahun 2016 tentang Perangkat Daerah, Peraturan Daerah Nomor 8 Tahun 2016 tentang Pembentukan dan Susunan Perangkat Daerah Kota Bitung, serta Peraturan Wali Kota Bitung Nomor 54 Tahun 2016 tentang Kedudukan, Susunan Organisasi, Tugas dan Fungsi serta Tata Kerja Badan Kepegawaian Pendidikan dan Pelatihan Daerah Kota Bitung. Sementara itu, hasil observasi penulis menilai bahwa pada awalnya organisasi BKPPD mampu menyesuaikan diri dengan perubahan struktur yang ada, akan tetapi seiring berjalannya waktu dalam penyelenggaraan organisasi ini mengalami kesulitan dalam melaksanakan tugas dan fungsinya. Perubahan struktur tersebut berpengaruh pada berkurangnya jumlah SDM, yaitu sebanyak lima orang, anggaran, program dan kegiatan yang sudah disusun sebelumnya serta beban kerja yang dirasakan para pegawai semakin besar sehingga membutuhkan waktu kerja yang lebih lama. Oleh karena itu dapat disimpulkan organisasi BKPPD Kota Bitung belum mampu menyesuaikan diri dengan perubahan yang ada. Beban kerja yang besar akibat perampingan struktur ini sangat dirasakan para pegawai sehingga mengharuskan para pegawai memiliki alokasi waktu kerja yang lebih lama dari standar yang ditentukan.

\section{Produktivitas}

Berdasarkan hasil wawancara dengan Kasubbag Umum dan Perlengkapan Ruben Binanggal, dikatakan bahwa:

"sebagai contoh konkret yang kami alami ketika menumpuknya antrean pegawai yang datang untuk mengurus berkas misalnya kenaikan pangkat, karena terbatasnya pegawai yang ada, sehingga saya lihat tidak produktif karena waktu istirahat makan pegawai pun terpakai untuk pelayanan kepada ASN yang mengurus berkas. Ketika kami pegawai BKPPD istirahat makan siang, pada saat kembali lagi pekerjaan sudah menumpuk. Sama halnya juga ketika ada pegawai yang sakit, ketika kembali bekerja pekerjaannya sudah menumpuk"

Lebih lanjut dijelaskan Sekretaris BKPPD Junitje Pangkerego yang ditemui penulis pada 11 Maret 2019 pukul 11.30 WITA bertempat di ruang kerjanya bahwa:

"Produktivitas dapat dikatakan masih kurang, hal ini ya karena beban 
kerja yang besar sehingga terkadang pekerjaan terbengkalai. Pegawai masih mengerjakan pekerjaan lain sementara ada pekerjaan lain juga yang harus dikerjakan dalam waktu yang sama. Contohnya pada bidang diklat, mutasi dan pengembangan SDM banyak pegawai yang datang untuk mengambil SK pelantikan sementara para pegawai sedang tidak berada di tempat karena harus mengurus pelaksanaan diklatpim IV di Naimundung".

Senada dengan hal itu dijelaskan oleh salah satu staf pada seksi dokumentasi, pengolahan data dan informasi Ryan:

"Saat ini kalau kita lihat ada pekerjaan tidak memenuhi anjab abk yang mengakibatkan ada beberapa pekerjaan yang harus dikerjakan oleh satu orang sehingga kami sendiri kelabakan dalam bekerja".

Berdasarkan data, hasil wawancara dan observasi yang penulis lakukan dapat disimpulkan bahwa akibat dari adanya perubahan struktur Badan Kepegawaian Pendidikan dan Pelatihan Daerah Kota Bitung dengan Tipe $\mathrm{C}$ berpengaruh pada tingkat produktivitas organisasi baik individu, kelompok maupun keseluruhan organisasi. Jika dilihat dari ketiga hal tersebut organisasi BKPPD ini belum produktif hal dikarenakan banyaknya pekerjaan yang harus dikerjakan sementara jumlah pegawai atau SDM terbatas sehingga adanya pekerjaan yang terabaikan karena harus mengerjakan pekerjaan yang lain. Dalam mengerjakan pekerjaan baik individu atau pegawai, unit kerja atau kelompok juga membutuhkan waktu yang ekstra atau lebih yang menyebabkan pegawai harus lembur, sementara jam lembur pegawai tidak dibarengi dengan upah atau kesejahteraan pegawai. Sehingga menurut penulis banyaknya beban kerja pegawai yang juga berpengaruh pada jam kerja pegawai harus diimbangi dengan tingkat kesejahteraan pegawai juga sehingga organisasi dapat berjalan produktif.

\section{Kepuasan Kerja}

Sebagaimana dikatakan Kepala BKPPD Franky Ladi yang ditemui di ruang kerjanya bahwa:

"Ya kalau saya pribadi cukup puas dengan hasil kerja dari para pegawai atau bawahan saya, sekali pun dengan keterbatasan SDM sementara banyak pekerjaan, mereka selalu berusaha menyelesaikan pekerjaan

Tabel 2 Target dan Realisasi Kinerja BKPPD Kota Bitung Tahun 2017

\begin{tabular}{|c|c|c|c|c|}
\hline Sasaran Strategis & Indikator Kinerja & Target PNS & Realisasi & $\%$ \\
\hline $\begin{array}{l}\text { Meningkatnya Kualitas Sumber } \\
\text { Daya Manusia Aparatur }\end{array}$ & $\begin{array}{l}\text { Presentasi Pejabat Struktural } \\
\text { yang mengikuti Diklatpim III, II }\end{array}$ & 43 & 42 & 98 \\
\hline \multirow{2}{*}{$\begin{array}{l}\text { Terwujudnya pelayanan publik } \\
\text { di bidang kepegawaian yang } \\
\text { berbasis teknologi, }\end{array}$} & $\begin{array}{l}\text { Tersedianya Sistem Kenaikan } \\
\text { Pangkat Otomatis }\end{array}$ & 900 & 420 & 46 \\
\hline & $\begin{array}{l}\text { Tersedianya Sistem Kenaikan } \\
\text { Gaji Berkala }\end{array}$ & 900 & 1504 & 167 \\
\hline \multirow{2}{*}{$\begin{array}{l}\text { Meningkatnya } \\
\text { Informasi Kepegawaian }\end{array}$} & $\begin{array}{l}\text { Presetanse Record yang di } \\
\text { updating }\end{array}$ & 100 & 55 & 55 \\
\hline & $\begin{array}{l}\text { Jumlah Pengembangan Aplikasi } \\
\text { Sistem Informasi BKPPD }\end{array}$ & 1 Aplikasi & 1 & 100 \\
\hline
\end{tabular}

Sumber: LAKIP BKPPD Kota Bitung Tahun 2017 
walaupun harus lembur pulang kantor sudah malam".

Lebih lanjut dikatakan Herny Posumah selaku Kepala Bidang Pembinaan Umum dan Informasi Kepegawaian, bahwa:

"Selama ini reward atau penghargaan yang diberikan seperti mengikuti diklatdilat kepegawaian tetapi hanya untuk 1-2 orang saja. Untuk penghargaan lain atau jam lembur tidak dihitung".

Sependapat dengan hal itu Kepala Bidang Diklat, Mutasi dan Pengembangan Aparatur Richard Wowiling mengatakan:

"Sebagai pimpinan saya puas dengan hasil kerja para pegawai BKPPD selama ini, bentuk penghargaan memang masih minim biasanya berupa diklat-diklat kepegawaian untuk beberapa orang saja, kalau jam lembur memang hampir selalu ada yang lembur, pulang kerja sudah malam akan tetapi karena keterbatasan anggaran juga sehingga belum ada perhitungan dan penghargaan jam lembur bagi pegawai. Hampir rata-rata pegawai di sini sudah lama makanya sudah terbiasa dengan pekerjaan yang menyita waktu lebih".

Berdasarkan hasil wawancara di atas dapat disimpulkan bahwa pimpinan organisasi Badan Kepegawaian Pendidikan dan Pelatihan Daerah Kota Bitung baik Kepala, Sekretaris, Kepala Sub Bagian, Kepala Bidang dan Kepala Seksi merasa puas dengan hasil kerja para pegawainya. Hal ini dilihat dari usaha, kerja keras serta loyalitas para pegawai atas perintah serta tugas dan fungsinya dalam rangka pelayanan kepada para seluruh pegawai atau ASN yang ada di Kota Bitung. Akan tetapi kepuasan kerja yang dirasakan pimpinan organisasi tersebut berbanding terbalik dengan tingkat kepuasan individu atau pegawai (staf). Hal ini dikarenakan tidak sebandingnya pekerjaan yang dikerjakan dengan reward atau penghargaan yang diberikan bagi para pegawai. Reward atau penghargaan yang diberikan baik berupa kesempatan mengikuti diklat-diklat, pengembangan karier atau promosi jabatan, serta tingkat kesejahteraan pegawai masih sangat minim dan terbatas. Pemberian reward ini akan sangat berpengaruh pada motivasi kerja pegawai yang akan memicu semangat kerja pegawai. Semangat kerja pegawai akan menunjukkan kepuasan kerja pegawai juga sehingga pada akhirnya organisasi ini dapat berjalan secara efektif.

\section{Pencarian Sumber Daya}

Berdasarkan hasil wawancara dengan Kepala Bidang Diklat, Mutasi dan Pengembangan Aparatur, Richard Wowiling, dikatakan bahwa:

"Kalau dilihat dari segi beban kerja khususnya bidang diklat, mutasi dan pengembangan aparatur jadi lebih besar karena dari yang dulunya 4 bidang sekarang menjadi 2 bidang, jadi ada penumpukan kerja, yang dulunya pejabat pengambil keputusan secara strategis dalam tataran kepala bidang sekarang tinggal 2, butuh pemikiran yang luas lagi karena harus fokus pada 2 tugas yang berbeda yakni diklat dan mutasi. Contoh konkretnya saat ini ada 2 kegiatan yang berbeda, periode pangkat dan pelaksanaan diklat, yang kami rasakan sangat kekurangan personel akhirnya kami harus pintar membagi waktu untuk melaksanakan kedua kegiatan tersebut dan memprioritaskan pelaksanaan kegiatan diklat, sementara periode pangkat sedikit terabaikan".

Lebih lanjut dijelaskan oleh Sekretaris, Junitje Pangkerego, bahwa:

"SDM masih sangat dibutuhkan, begitu juga anggaran bisa dibicarakan dengan bagian keuangan. Sarana prasarana masih kurang juga dapat dilihat sendiri ya seperti inilah keadaannya masih banyak kekurangan". 
Vol. $12 \backslash$ No.4 \ Desember 2020: 789-806

Tabel 3 Jumlah Pegawai BKPPD Kota Bitung

\begin{tabular}{lc}
\hline \multicolumn{1}{c}{ Jabatan } & Jumlah \\
\hline Kepala Badan & 1 \\
Sekretaris & 1 \\
Kepala Bidang & 2 \\
Kepala Sub Bagian & 2 \\
Kepala Seksi & 4 \\
Fungsional umum & 21 \\
\hline Jumlah & 31 \\
\hline
\end{tabular}

Sumber: Renstra BKPPD Kota Bitung

Hasil perhitungan analisis beban kerja (ABK) dengan 10 (sepuluh) uraian tugas yang dimiliki Kepala Bidang Diklat, Mutasi dan Pengembangan Aparatur membutuhkan dua orang untuk mengerjakan uraian-uraian tugas di atas. Hal ini membuktikan bahwa beban kerja yang diemban sangat besar. Oleh karena itu organisasi BKPPD Kota Bitung masih membutuhkan penambahan sumber daya manusia dalam menciptakan organisasi yang efektif. Selain sumber daya manusia, sumber daya pendukung seperti sarana dan prasarana umumjuga merupakan unsur penunjang penyelenggaraan tugas dan fungsi organisasi Badan Kepegawaian Pendidikan dan Pelatihan Daerah Kota Bitung.

Sebagaimana hasil observasi, studi dokumentasi serta hasil wawancara penulis di atas dapat disimpulkan bahwa dalam penyelenggaraan organisasi Badan Kepegawaian Pendidikan dan Pelatihan Daerah Kota Bitung masih sangat membutuhkan sumber daya pendukung baik sumber daya manusia, serta sarana dan prasarana penunjang penyelenggaraan organisasi. Sumber daya manusia merupakan unsur penting dalam penyelenggaraan organisasi oleh karena itu pemerintah harus memperhatikan dan mengkaji kembali struktur organisasi yang ada sehingga akan didukung dengan adanya penambahan jumlah pegawai yang ada di Badan Kepegawaian Pendidikan dan Pelatihan Daerah Kota Bitung sesuai dengan kebutuhan begitu juga dengan sarana dan prasarana pendukung masih dibutuhkan penambahan sehingga dapat maksimal dalam penyelenggaraan tugas dan fungsi organisasi BKPPD yang efektif.

\section{Faktor-Faktor yang Memengaruhi Efektivitas Organisasi}

\section{- Karakteristik Organisasi}

\section{- Desentralisasi}

Stephen P Robbins dalam buku Perilaku Organisasi (2008) desentralisasi merupakan pengambilan keputusan dengan melibatkan para perangkat/individu tingkat bawah.

Dari hasil observasi penulis serta hasil wawancara di atas penulis dapat menyimpulkan bahwa dalam Penyelenggaraan organisasi khususnya dalam pengambilan keputusan pimpinan organisasi selalu melibatkan para perangkat atau pegawainya. Hal ini didukung dengan adanya jadwal rutin pelaksanaan rapat kerja Badan Kepegawaian Pendidikan dan Pelatihan Daerah Kota Bitung yang dilaksanakan dua kali dalam sebulan. Rapat kerja ini dilaksanakan secara keseluruhan organisasi juga pada masing-masing unit kerja organisasi. Sehingga dalam pelaksanaan tugas lebih terarah.

\section{- Spesialisasi}

Taylor dalam Steers (1985) berpendapat bahwa "salah satu faktor utama penentu keberhasilan organisasi adalah kemampuan organisasi membagi-bagi fungsi kerjanya menjadi kegiatan-kegiatan yang sangat khusus.

Dari hasil observasi dan wawancara di atas dapat disimpulkan bahwa tingkat pembagian tugas organisasi atau spesialisasi organisasi sudah baik di mana pembagian tugas sudah didasarkan pada keahlian dan 
kemampuan serta latar belakang masingmasing pegawai, selain itu juga dilihat dari pengalaman kerja pegawai. Sehingga dalam pelaksanaan tugas dan fungsinya para pegawai mampu menyelesaikan setiap pekerjaannya.

\section{- Formalisasi}

Stephen P. Robbins dalam buku Perilaku Organisasi (2008) mengemukakan formalisasi merupakan tingkat di mana pekerjaan itu dibakukan. Hal ini dapat dilihat dari banyaknya aturan dalam organisasi, adanya uraian jabatan yang tersurat, serta memiliki prosedur yang jelas dalam proses kerja pada organisasi.

Dari hasil observasi, studi dokumentasi dan wawancara di atas dapat disimpulkan bahwa dalam penyelenggaraan tugas organisasi Badan Kepegawaian Pendidikan dan Pelatihan Daerah Kota Bitung didasarkan pada aturan-aturan yang berlaku yang kemudian dijabarkan dalam suatu pedoman penyelenggaraan tugas dalam hal ini Standar Operasional Prosedur (SOP) yang dimiliki masing-masing unit kerja. Dalam aplikasinya sehari-hari pada pekerjaan tertentu harus keluar dari SOP hal ini disesuaikan dengan kondisi yang dialami pada saat itu dalam rangka mempermudah penyelesaian tugas dan pelayanan organisasi.

\section{- Rentang Kendali}

Dari pendapat Stephen P Robbins dalam buku Perilaku Organisasi (2008) dapat disimpulkan Rentang kendali merupakan seberapa banyak jumlah bawahan yang dapat diatur oleh manajer secara efisien dan efektif. Apabila semakin besar rentangnya, maka organisasi semakin efektif.

Berdasarkan hasil observasi dan wawancara di atas dapat disimpulkan bahwa tingkat rentang kendali masih kurang hal ini dikarenakan masih terbatasnya jumlah pegawai atau staf pada masing-masing unit kerja dan juga masih ada beberapa jabatan yang kosong belum terisi seperti Kepala Seksi Dokumentasi, Pengolahan Data dan Informasi, Kepala Seksi Pengadaan dan Perpindahan Pegawai serta terdapat empat jabatan fungsional staf, yang menyebabkan bertumpuknya pekerjaan pada unit-unit kerja yang ada sehingga kurang efektifnya pelaksanaan tugas dan fungsi organisasi Badan Kepegawaian Pendidikan dan Pelatihan Daerah Kota Bitung.

\section{- Ukuran Organisasi}

Richard M. Steers (1985) Besarnya ukuran organisasi memiliki hubungan dengan peningkatan efektivitas dalam organisasi. Hal ini dapat dilihat dari aspekaspek yang mengatur pelaksanaan pekerjaan secara tertib dan efisien seperti pergantian pemimpin yang teratur, berkurangnya biaya tenaga kerja dan pengendalian lingkungan.

Dengan melihat pada hasil observasi, studi dokumentasi serta hasil wawancara di atas dapat disimpulkan bahwa ukuran organisasi Badan Kepegawaian Pendidikan dan Pelatihan Daerah Kota Bitung masih membutuhkan penambahan unit kerja yang dibarengi juga dengan penambahan sumber daya manusia sehingga ada pembagian tugas secara merata serta mengurangi beban kerja yang dirasakan pegawai dalam rangka peningkatan dan efektifnya pelayanan yang diberikan.

\section{- Ukuran Unit Kerja}

Besar unit kerja berbeda pengaruhnya terhadap sikap dan tingkah laku para pekerja dan pengaruhnya terhadap organisasi. Kemungkinan dikatakan faktor bertambahnya kesempatan bergabung yang biasanya diasosiasikan dengan kelompok kerja yang lebih kecil seperti pendapat Cartwright \& Zander (1968). Dengan adanya kelompok kecil ini memudahkan para anggota kelompok saling mengenal dengan baik, menjalin persahabatan serta membangun persatuan kelompok. 
Berdasarkan hasil observasi dan wawancara yang dilakukan penulis di atas dapat disimpulkan bahwa ukuran unit kerja pada Badan Kepegawaian, Pendidikan dan Pelatihan Kota Bitung masih sangat kecil. Dibutuhkan penambahan unit kerja sehingga adanya pemerataan pembagian tugas dan semua pekerjaan dapat dikerjakan dan diselesaikan secara cepat dan tepat. Dengan adanya penambahan unit kerja ini masih memungkinkan organisasi atau para pegawai menjalin hubungan yang baik satu dengan yang lain serta tingkat persatuan dan kesatuan akan terjaga dengan baik pula.

\section{- Karakteristik Lingkungan}

\section{- Tingkat Keterdugaan Keadaan Lingkungan}

Berdasarkan hasil observasi dan wawancara di atas dapat disimpulkan bahwa tingkat keterdugaan lingkungan organisasi Badan Kepegawaian, Pendidikan dan Pelatihan Daerah Kota Bitung ini sudah baik. Kemampuan organisasi untuk dapat membaca situasi atau lingkungannya serta kemungkinan-kemungkinan yang bisa terjadi dan juga penentuan strategi yang tepat oleh organisasi ini dinilai sangat baik.

\section{- Ketepatan Persepsi Keadaan Lingkungan}

Ketepatan persepsi atas keadaan lingkungan di mana para manajer membuat tanggapan atas apa yang mereka lihat.

Dari hasil observasi dan wawancara di atas dapat disimpulkan bahwa ketepatan persepsi terhadap keadaan lingkungan sudah baik. Para manajer mampu memperhatikan kemungkinan-kemungkinan yang bisa terjadi sehingga menjaga organisasi tetap efektif dalam pelaksanaan program dan kegiatan sebagaimana yang telah direncanakan.

\section{- Rasionalitas Dalam Pengambilan Keputusan}

Tingkat rasionalitas organisasi, di mana para manajer dituntut untuk dapat mengambil keputusan secara tepat dan rasional untuk menanggapi perubahan lingkungan yang terjadi. Makin rasional proses pemilihan alternatif yang ada, makin besar pula kemungkinan bahwa tanggapan yang dipilih akan cocok dengan tuntutan lingkungannya.

Hasil wawancara dengan staf seksi dokumentasi, pengolahan data dan informasi Ryan, ST mengatakan bahwa:

"Sudah pernah kita buat gudang data dalam bentuk softcopy ruangannya ada di ruang kerja kepala badan, tetapi sangat disayangkan kita terhambat pada permintaan data para ASN. Makanya dialihkan dengan pengumpulan data dalam bentuk softcopy pada perangkat hardware dengan cara di-scan. Yang mana pegawai datang membawa berkasnya kemudian kita scan di sini untuk disimpan dalam bentuk file".

Melalui contoh kasus di atas menunjukkan bahwa langkah atau strategi yang diambil pimpinan organisasi sudah tepat yakni dengan mengantisipasinya melalui pengumpulan data dengan cara discan dan dibuatkan file pada perangkat hardware atau komputer.

Dengan adanya langkah atau kebijakan lain yang diambil pimpinan maka program ini tetap berjalan sebagaimana mestinya sekali pun dengan cara atau langkah yang berbeda. Hal ini membuktikan bahwa organisasi ini berorientasi pada pelayanan dan pelaksanaan tugasnya sekali pun dalam proses penyelenggaraannya memiliki banyak hambatan, tetapi kemampuan pimpinan dalam memberikan respons atau ketanggapan sangat tepat. 


\section{- Ketepatan Tanggapan Organisasi terhadap Perubahan}

Dengan memperhatikan tingkat kerumitan, kemantapan dan ketidakpastian yang terdapat dalam lingkungan luar organisasi maka organisasi dapat memberikan tanggapan yang tepat dan mengadakan penyesuaian diri secara tepat juga.

Dengan demikian dapat dilihat bahwa organisasi Badan Kepegawaian, Pendidikan dan Pelatihan Daerah Kota Bitung tanggap dalam menghadapi perubahan yang terjadi seperti pada contoh kasus pembuatan gudang data pegawai. Perubahan yang terjadi menuntut organisasi untuk cepat tanggap baik mempersiapkan kemampuan masingmasing pegawai juga sarana prasarana atau perangkat yang dibutuhkan dalam rangka pelaksanaan program dan kegiatan organisasi yang efektif.

\section{- Karakteristik Pekerja}

\section{- Ketertarikan pada Pekerjaan}

Dalam organisasi pekerja merupakan salah satu faktor pendukung keberhasilan organisasi. Tanpa pekerja organisasi tidak dapat berfungsi. Selain itu bagaimana tingkat ketertarikan pada pekerjaan juga akan memengaruhi para pekerja dalam melaksanakan tugasnya.

Dari hasil observasi penulis di lapangan dan hasil wawancara di atas dapat dilihat bahwa tingkat ketertarikan pegawai akan pekerjaannya sudah mulai berkurang atau menurun dikarenakan periode waktu lamanya bekerja di Badan Kepegawaian, Pendidikan dan Pelatihan Daerah Kota Bitung. Hal ini membuat para pegawai tidak tertarik lagi dengan pekerjaannya karena pekerjaan tersebut sudah sering dilakukan dalam kurun waktu yang lama sehingga sifatnya monoton, serta kurangnya tantangan dalam melakukan pekerjaan tersebut. Tentunya ini akan sangat memengaruhi efektivitas organisasi dalam penyelenggaraan tugas dan fungsinya.

\section{- Kemantapan Kerja}

Pekerja dapat memengaruhi keefektifan suatu organisasi. Terciptanya tujuan organisasi tergantung pada kemampuan pekerja yang dimiliki organisasi tersebut. Kemampuan pekerja dapat dilihat dari kemantapan pekerja dalam mengerjakan dan menyelesaikan tugasnya secara efektif, efisien dan cepat.

Berdasarkan hasil observasi dan hasil wawancara di atas dapat disimpulkan bahwa tingkat kemantapan kerja para pegawai sudah baik. Totalitas dalam bekerja merupakan modal para pegawai dalam melaksanakan tugasnya sekali pun belum dibarengi dengan tingkat kesejahteraan yang diterima pegawai. Kemantapan kerja inilah yang mendukung terciptanya efektivitas organisasi pada Badan Kepegawaian, Pendidikan dan Pelatihan Daerah Kota Bitung.

\section{- Komitmen}

Dalam mengerjakan suatu pekerjaan sangat dibutuhkan ketaatan terhadap aturan yang berlaku serta konsistensi dalam bekerja. Konsistensi ini dibangun dari kesadaran pegawai akan tugas dan tanggung jawabnya sebagai Aparatur Sipil Negara bukan dari tuntutan pemimpin organisasi. Sehingga pada akhirnya hal ini menjadi budaya atau kebiasaan yang melekat pada masing-masing pegawai.

Dari hasil observasi dan wawancara di atas dapat disimpulkan bahwa tingkat komitmen para pegawai Badan Kepegawaian, Pendidikan dan Pelatihan Daerah Kota Bitung sudah baik. Hal ini dapat dilihat dari tingkat disiplin pegawai terhadap jam kerja, disiplin dalam berpakaian dengan menggunakan atribut yang lengkap yang juga diterapkan bagi setiap ASN yang datang ke kantor Badan Kepegawaian, Pendidikan dan Pelatihan 
Daerah Kota Bitung serta disiplin dalam mengerjakan tugas dan tanggung jawabnya sehingga dapat menunjang efektivitas organisasi Badan Kepegawaian, Pendidikan dan Pelatihan Daerah Kota Bitung sendiri.

\section{- Prestasi Kerja}

Pencapaian akan hasil dari pekerjaan yang dikerjakan secara maksimal adalah sebuah prestasi. Prestasi merupakan kepuasan tersendiri yang dirasakan oleh individu ataupun organisasi atas kerja keras yang dilakukan individu atau organisasi tersebut.

Dari hasil studi dokumentasi dan wawancara di atas dapat disimpulkan bahwa organisasi Badan Kepegawaian, Pendidikan dan Pelatihan Daerah Kota Bitung sudah baik. Prestasi yang baik tentunya akan menunjang keberlangsungan organisasi dalam rangka terciptanya efektivitas organisasi.

\section{- Kebijakan dan Praktik Manajemen}

\section{- Musyawarah}

Kebijakan yang baik adalah kebijakan yang berjalan sesuai dengan tujuan yang dituju. Kebijakan itu sendiri ditentukan oleh pengambil kebijakan dan pelaksana kebijakan yang dapat dilakukan melalui proses musyawarah untuk mencapai mufakat.

Didasarkan pada hasil observasi dan wawancara di atas dapat disimpulkan bahwa dalam penyelenggaraan organisasi khususnya dalam pengambilan keputusan selalu didasarkan pada hasil musyawarah dengan mempertimbangkan berbagai masukan, saran dan pendapat dari para pejabat pengambil keputusan strategis dalam organisasi. Hal ini tentunya merupakan suatu sikap yang baik yang diambil pimpinan organisasi dalam menciptakan efektivitas organisasi Badan Kepegawaian, Pendidikan dan Pelatihan Daerah Kota Bitung.

\section{- Komunikasi}

Keberlangsungan suatu organisasi akan berjalan baik ketika adanya koordinasi dan komunikasi yang baik pula baik antarsesama bawahan atau staf maupun antara bawahan dan atasan atau sebaliknya.

Berdasarkan observasi penulis di lapangan dan hasil wawancara di atas dapat disimpulkan bahwa sistem koordinasi dan komunikasi yang terbangun di antara para staf sudah baik dengan memanfaatkan media sosial sebagai alat komunikasi satu dengan yang lain. Akan tetapi jika dilihat dari sistem komunikasi dan koordinasi antara pimpinan dan bawahan masih kurang akibat dari banyaknya pekerjaan yang harus dikerjakan dan diawasi oleh para kepala bidang sehingga adanya pekerjaan yang terabaikan dan hal ini tentunya akan memengaruhi efektivitas organisasi.

\section{- Kepemimpinan}

Kepemimpinan dalam suatu organisasi memiliki pengaruh yang besar dalam penyelenggaraan organisasi. Cara memimpin maupun mengambil keputusan adalah bentuk dari kepemimpinan itu.

Dari hasil observasi dan wawancara di atas penulis dapat menyimpulkan bahwa pola atau tipe kepemimpinan yang ada di Badan Kepegawaian, Pendidikan dan Pelatihan Daerah Kota Bitung sudah baik. Pemberian motivasi kerja, kerendahan hati, mengayomi, merangkul, mau mendengar merupakan sikap yang baik yang dimiliki oleh pimpinan organisasi sehingga para bawahan merasakan kenyamanan dalam bekerja. Dengan pola Kepemimpinan inilah yang menumbuhkan sikap loyalitas yang tinggi dari para bawahannya.

\section{- Pengambilan Keputusan}

Sama halnya dengan manajemen yakni berbicara mengenai apa yang harus diputuskan untuk dilaksanakan oleh 
para individu-individu dalam organisasi. Sehingga kebijakan dan praktik manajemen ini membutuhkan peran besar dari seorang manajer dalam memimpin organisasi untuk tercapainya tujuan organisasi tersebut.

Dari hasil observasi dan wawancara di atas dapat disimpulkan bahwa dalam pengambilan keputusan pimpinan organisasi selalu melibatkan para bawahannya, sehingga hal ini merupakan nilai positif yang dilihat oleh bawahan bahwa mereka ikut serta terlibat dalam pengambilan keputusan organisasi. Selain itu hal ini juga sebagai bentuk penghargaan bagi para bawahan karena pendapat mereka bisa didengarkan oleh pimpinan selaku pejabat pembuat keputusan.

\section{ASOCA}

Berdasarkan hasil analisis ASOCA dan litmus test yang dilakukan, maka diperoleh isu strategis dalam meningkatkan efektivitas organisasi Badan Kepegawaian, Pendidikan dan Pelatihan Daerah Kota Bitung yang dapat dikategorikan sebagai berikut.

\section{- Isu Strategis}

a. Meningkatkan kemampuan menyesuaikan diri organisasi BKPPD dalam menghadapi berbagai perubahan baik pada struktur organisasi, rencana kerja atau program kerja organisasi.

b. Memanfaatkan kemampuan dan pengalaman kerja SDM untuk mengembangkan diriatau dipromosikan.

c. Meningkatkan kemampuan dalam memberikan pelayanan melalui cara kerja yang modernisasi

d. Meningkatkan sistem koordinasi dalam organisasi BKPPD baik antarsesama staf, maupun staf dengan pimpinan ataupun sebaliknya.

e. Meningkatkan peran BKPPD dalam menjaga konsistensi penyelenggaraan tugas dan fungsi sesuai peraturan yang berlaku.

\section{- Isu Sangat Strategis}

a. Peningkatan manajemen sistem kepegawaian yang berkualitas melalui inovasi-inovasi baru.

b. Memaksimalkan kemampuan dan kecerdasan berinovasi SDM untuk melahirkan strategi yang dibutuhkan dalam meningkatkan efektivitas organisasi BKPPD seiring dengan perkembangan teknologi yang didukung oleh tersedianya sarana dan prasarana.

c. Memaksimalkan penyelenggaraan tugas dan fungsi dan pengawasan dalam bentuk reward dan punishment.

d. Meningkatkan kemampuan SDM melalui pendidikan dan pelatihan yang merupakan hasil kerja sama dengan pihak luar.

\section{SIMPULAN}

Pertama, efektivitas organisasi Badan Kepegawaian Pendidikan dan Pelatihan Daerah kota Bitung masih kurang dan membutuhkan perbaikan lagi. Hal ini dapat dilihat dari beberapa indikator, yaitu sebagai berikut.

a. Produktivitas, akibat dari adanya perubahan struktur Badan Kepegawaian Pendidikan dan Pelatihan Daerah Kota Bitung dengan Tipe $\mathrm{C}$ adalah tingkat produktivitas organisasi ini masih kurang hal ini dikarenakan banyaknya pekerjaan yang harus dikerjakan sementara jumlah pegawai atau SDM terbatas sehingga adanya pekerjaan yang terabaikan karena harus mengerjakan pekerjaan yang lain.

b. Pencariansumberdaya, penyelenggaraan organisasi Badan Kepegawaian Pendidikan dan Pelatihan Daerah Kota Bitung masih sangat membutuhkan sumber daya pendukung baik sumber daya manusia, serta sarana dan prasarana penunjang penyelenggaraan organisasi. 
Sumber daya manusia merupakan unsur penting dalam penyelenggaraan organisasi oleh karena itu pemerintah harus memperhatikan dan mengkaji kembali struktur organisasi yang ada sehingga akan didukung dengan adanya penambahan jumlah pegawai yang ada di Badan Kepegawaian Pendidikan dan Pelatihan Daerah Kota Bitung sesuai dengan kebutuhan begitu juga dengan sarana dan prasarana pendukung masih dibutuhkan penambahan sehingga dalam dapat maksimal dalam penyelenggaraan tugas dan fungsinya.

Kedua, efektivitas organisasi Badan Kepegawaian Pendidikan dan Pelatihan Daerah Kota Bitung berdasarkan hasil penelitian ini dinilai masih kurang hal ini dipengaruhi oleh beberapa faktor antara lain sebagai berikut.

a. Rentang Kendali, bahwa tingkat rentang kendali masih kurang hal ini dikarenakan masih terbatasnya jumlah pegawai atau staf pada masing-masing unit kerja dan juga masih ada beberapa jabatan yang kosong belum terisi seperti Kepala Seksi Dokumentasi, Pengolahan Data dan Informasi, Kepala Seksi Pengadaan dan Perpindahan Pegawai serta terdapat empat jabatan fungsional staf, yang menyebabkan bertumpuknya pekerjaan pada unit-unit kerja yang ada sehingga kurang efektifnya pelaksanaan tugas dan fungsi organisasi Badan Kepegawaian Pendidikan dan Pelatihan Daerah Kota Bitung.

b. Ukuran Organisasi, ukuran organisasi Badan Kepegawaian Pendidikan dan Pelatihan Daerah Kota Bitung masih membutuhkan penambahan unit kerja yang dibarengi juga dengan penambahan sumber daya manusia sehingga ada pembagian tugas secara merata serta mengurangi beban kerja yang dirasakan pegawai dalam rangka peningkatan dan efektifnya pelayanan yang diberikan. c. Ukuran Unit Kerja, ukuran unit kerja pada Badan Kepegawaian, Pendidikan dan Pelatihan Kota Bitung masih sangat kecil. Dibutuhkan penambahan unit kerja sehingga adanya pemerataan pembagian tugas dan semua pekerjaan dapat dikerjakan dan diselesaikan secara cepat dan tepat. Dengan adanya penambahan unit kerja ini masih memungkinkan organisasi atau para pegawai menjalin hubungan yang baik satu dengan yang lain serta tingkat persatuan dan kesatuan akan terjaga dengan baik pula.

Ketiga, dengan melihat beberapa kekurangan dalam meningkatkan efektivitas organisasi Badan Kepegawaian, Pendidikan dan Pelatihan Kota Bitung maka ditemukan strategi untuk meningkatkan efektivitas organisasi BKPPD:

a. Meningkatkan kemampuan SDM melalui pendidikan dan pelatihan yang merupakan hasil kerja sama dengan pihak luar.

b. Peningkatan manajemen sistem kepegawaian yang berkualitas melalui inovasi-inovasi baru.

c. Memaksimalkan penyelenggaraan tugas dan fungsi dan pengawasan dalam bentuk reward dan punishment.

d. Memaksimalkan kemampuan dan kecerdasan berinovasi SDM untuk melahirkan strategi yang dibutuhkan dalam meningkatkan efektivitas organisasi BKPPD seiring dengan perkembangan teknologi yang didukung oleh tersedianya sarana dan prasarana.

\section{SARAN}

Berdasarkan simpulan di atas, maka penulis memberikan beberapa saran antara lain sebagai berikut.

Pertama, dalam rangka meningkatkan efektivitas organisasi Badan Kepegawaian, 
Pendidikan dan Pelatihan Daerah Kota Bitung setelah adanya perubahan struktur sebaiknya tingkat produktivitas kerja para pegawai ditingkatkan lagi dengan cara penambahan SDM serta Sarana Prasarana penunjang keberlangsungan organisasi sehingga organisasi dalam memberikan pelayanan dapat optimal.

Kedua, memperhatikan serta mengkaji kembali komposisi atau struktur yang ada, penambahan jabatan struktural akan mempermudah organisasi dalam melaksanakan tugas dan fungsinya sehingga organisasi berjalan efektif.

Ketiga, organisasi Badan Kepegawaian, Pendidikan dan Pelatihan Kota Bitung mampu melihat perkembangan teknologi dan memanfaatkan kemampuan pegawai sebagai peluang dalam rangka pengembangan kualitas organisasi baik individu atau pegawai maupun secara keseluruhan organisasi. Seperti adanya sistem kepegawaian yang berbasis teknologi serta inovasi-inovasi baru lainnya.

\section{DAFTAR PUSTAKA}

Arikunto, Suharsimi. 2010. Prosedur Penelitian. Jakarta: PT.Rineka Cipta.

Basrowi dan Suwandi. 2008. Memahami Penelitian Kualitatif. Jakarta: Rineka Cipta.

Gibson, James L. et al. 1996. Organisasi: Perilaku, Struktur, Proses. Diterjemahkan oleh Ninuk Adriani. Jakarta: Binarupa Aksara.

Kountur Ronny. 2007. Metode Penelitian untuk penulisan Skripsi dan Tesis Penerbit PPM.

Moleong, Lexy J. 2013. Metode Penelitian Kualitatif. Edisi Revisi. Bandung: PT. Remaja Rosdakarya.

Muhadjir, Noeng. 1996. Metodologi Penelitian Kualitatif. Yogyakarta: Rake Sarasin

Nasution. 2009. Metode Research.Jakarta: PT Bumi Aksara

Nazir, Moh. 2009. Metode Penelitian. Bogor: Ghalia Indonesia.
(2013). Metode Penelitian. Bogor: Ghalia Indonesia.

Ndraha, Taliziduhu. 2003. Kybernology (Ilmu Pemerintahan Baru). Jilid 1-2. Jakarta: Rineka Cipta.

Noor, Juliansyah. 2011. Metodologi Penelitian. Kencana

Robbins, Stephen dan Timoty A. Judge. 2008. Perilaku Organisasi, Organizational Behaviour. Jakarta: Salemba Empat.

Tahir,Irwan dan Ani Martini, 2015. Mendesain Organisasi Perangkat Daerah Yang Efisien dan Efektif, Jatinangor: Penulisan Buku Literatur IPDN.

Thoha Miftah. 2002. Perspektif Perilaku Birokrasi. Jakarta: PT. Radja Grafindo Persada.

Sedarmayanti. 2010. Reformasi Administrasi Publik, Reformasi Birokrasi dan Kepemimpinan Masa Depan. Bandung: PT. Refika Aditama.

Sembiring, Masana 2012, Budaya dan Kinerja Organisasi. Bandung: Fokusmedia.

Simangunsong Fernandes, 2014,Transformasi Organisasi Perubahan Desa menjadi Kelurahan. Bandung: Penerbit Alfabeta.

-------------.. 2017, Metodologi Penelitian Pemerintahan. Bandung: Alfabeta.

Soehartono, Irawan. 2011. Metode Penelitian Sosial. Bandung: PT. Remaja Rosdakarya.

Steers, Richard M, 1985, Efektivitas Organisasi. Jakarta: Erlangga

Sugiyono. 2013. Metode Penelitian Kuantitatif, Kualitatif dan R\&D. Bandung: Alfabeta.

Suradinata, Ermaya,2010, Reformasi Organisasi dan Administrasi Pemerintahan, Jakarta: Lembaga Ketahanan Negara Republik Indonesia.

-------------. 2013. Analisis Kepemimpinan Strategi Pengambilan Keputusan ASOCA. Jatinangor: Alqaprint.

Wasistiono, Sadu. 2002. Evaluasi Pelaksanaan Otonomi Daerah Sebagai Upaya Awal Merevisi UU Nomor 22 dan 25 Tahun 1999. Bandung: Alqaprint.

Wursanto. 2003. Dasar-dasar Ilmu Organisasi. Yogyakarta: Andi. 
2005. Dasar-dasar Ilmu Organisasi. Yogyakarta: Andi.

\section{Peraturan Perundang-Undangan}

Undang-Undang Nomor 23 Tahun 2014 tentang Pemerintahan Daerah.

Peraturan Pemerintah Nomor 18 Tahun 2016 tentang Perangkat Daerah.

Peraturan Menteri Dalam Negeri Nomor 5 Tahun 2017 tentang Pedoman Nomenklatur Perangkat Daerah Provinsi dan Daerah Kabupaten Kota Yang Melaksanakan Fungsi Penunjang Penyelenggaraan Urusan Pemerintahan

Peraturan Daerah Nomor 8 Tahun 2016 tentang Pembentukan dan Susunan Perangkat Daerah Kota Bitung

Peraturan Wali Kota Bitung Nomor 54 tahun 2016 tentang Pembentukan dan Susunan Organisasi, Tugas dan Fungsi serta Tata Kerja Badan Kepegawaian Pendidikan dan Pelatihan Daerah Kota Bitung

\section{Sumber-Sumber Lain}

Mudjia Raharjo 2010 (online) 15 Halaman Tersedia: http://repository.upi. edu/20109/6/S_TE_1102479_Chapter3. pdf [5 Oktober]

Christian_Wayongkere, 2016. Perampingan OPD, 131 Jabatan di Pemkot Bitung hilang, (online). Tersedia: http:// manado.tribunnews.com/2016/09/08/ perampingan-opd-131-jabatan-dipemkot-bitung-hilang $[12$ Februari 2018]

HisamSam.2019.11PengertianBirokrasi Menurut Para Ahli Terlengkap. (Online) Tersedia: https://www.dosen pendidikan.com/11pengertian-birokrasi-menurut-paraahli-terlengkap/[6 Oktober 2018]

Wena Liza, 2014. Evaluasi Kurikulum Diklat Berbasis Kompetensi Dalam Meningkatkan Soft Competency Pelaksana Kementerian Keuangan: Studi pada Pusdiklat Pengembangan Sumber Daya Manusia, Badan Pendidikan dan Pelatihan Keuangan, Kementerian Keuangan (online) Tersedia:

http://repository.upi.edu/12799/4/T PK_1202174_Chapter1.pdf [6 Oktober 2018]

http://2frameit.blogspot.com/2011/06/teoriefektivitas-organisasi.html

[9 Agustus 2018]

http://www.definisi-pengertian.com/2015/07/ efektivitas-organisasi.html [9 Agustus 2018)

http://citrahutabarat.blogspot.com/2011/10/ konsep-efektivitas-organisasi.html [9 Agustus 2018)

http://staff.unila.ac.id/ekobudisulistio/ files/2013/09/01-Konsep-Birokrasi.pdf [6 Oktober 2018] 